\title{
An Incomplete Revolution: Corporate Governance Challenges of the London Assurance Company and the Limitations of the Joint-Stock Form, 1720-1725
}

\author{
MICHAEL ALDOUS \\ STEFANO CONDORELLI
}

The London Assurance (LA) was incorporated in 1720, marking a significant innovation in the marine insurance industry. Contemporaries anticipated joint-stock firms such as the LA would rapidly outcompete private underwriters, yet this outcome did not occur. The success of the private underwriters has been ascribed to their organizational form. This paper reassesses these explanations and finds that, rather than an a priori worse business model, various corporate governance challenges limited the LA's capacity to compete. This provides a more complete explanation for the relative failure of the joint-stock marine insurance companies and has implications for understanding the evolution of the corporate form in the eighteenth century.

(C) The Author 2019. Published by Cambridge University Press on behalf of the Business History Conference.

doi:10.1017/eso.2019.34

\begin{abstract}
Michael Aldous is a lecturer in Management at Queens Management School, Queens University Belfast. Contact information: Queens Management School, Riddel Hall, 185 Stranmillis Road, Belfast BT9 5EE, Northern Ireland. Tel: +44 (0)28 90974200. E-mail: m.aldous@qub.ac.uk.

Stefano Condorelur is an associate researcher at the Center for Global Studies of the University of Bern in Switzerland. Contact information: Center for Global Studies, University of Bern, Länggassstrasse 51, 3012 Bern, Switzerland. E-mail: stefano. condorelli@cgs.unibe.ch.

\footnotetext{
* Michael Aldous and Stefano Condorelli conceived and developed this article together. Michael Aldous wrote the sections: Introduction, Britain's Evolving Economy in the Early Eighteenth Century, The Incorporation Debate, Creating a Strategy and Structure (paragraphs 6-10); Stefano Condorelli wrote the sections: Establishing a Marine Insurance Corporation, Creating a Strategy and Structure (paragraphs,1-5, 11), An Evolving Strategy, Explaining These Outcomes.
} 


\section{Introduction}

The floatation of London Assurance (LA) and Royal Exchange Assurance (REA) in 1720 gave rise to fevered speculation. Between January 1720 and their market peak in the summer of that year, the share price of the LA increased by 4320 percent and that of the REA by 1343 percent; greatly outpacing the price of the South Sea Company (SSC), which rose in comparison by only 675 percent. ${ }^{1}$ Contemporaries saw incorporation as a promising innovation with the potential to transform not only the insurance industry, but international trade. It was claimed that these enterprises would be able to offer lower rates, better guarantees, and quicker processing of claims. ${ }^{2}$ There were high expectations that the two firms would soon outcompete private underwriters and capture the rapidly expanding marine insurance market. $^{3}$

Yet the English marine insurance market developed very differently. Private underwriters thrived, cooperating to form the powerful organization that would become Lloyd's. The two joint-stock companies managed to secure only 10 percent of the market when launched, a figure that declined to 3 percent in 1810.4

Why, then, did the joint-stock corporations fail to deliver the expected innovations and outcompete the private underwriters? Answering this question is of interest to economic and business historians, as it contributes to current debates examining why different organizational forms emerge, and how they affect firm and economic performance. ${ }^{5}$ Insurance is a particularly interesting industry in which to address these questions. Pearson and Yoneyama show that different organizational forms have been used across time and geography to varying degrees of success. ${ }^{6}$ The LA, as part of the first wave of widespread incorporation within the English economy, offers a pertinent case with which to address these debates.

1. The data are drawn from Frehen, Goetzmann, and Rouwenhorst, "New Evidence on the First Financial Bubble."

2. LMA/CLC/B/192/MS08760, "The special report from the [Parliamentary] committee appointed to inquire into ... all undertakings for purchasing joint stocks, or obsolete charters."

3. Haines, Chapters of Insurance History, 206. Also, Straus, Lloyd's: A Historical Sketch, 27-28.

4. A Letter to Jasper Vaux, p. 47, estimates that in 1720 the LA and REA represented together 10 percent of the market for shipping and freight, compared to only 3 percent in 1810 .

5. Guinanne et al., "Putting the Corporation in Its Place"; Musacchio and Turner, "Does the Law and Finance Hypothesis Pass the Test of History?"

6. Pearson and Yoneyama, Corporate Forms and Organisational Choice in International Insurance. 
The historiography of the LA and REA identifies two dominant explanations for their relative failure. First, recent explanations focus on the agency problems created by the highly discrete nature of the risks in marine insurance. ${ }^{7}$ This placed a premium on organizational forms that improved flows of information to mitigate threats of asymmetric information. The system of networked private underwriting was particularly adept at addressing these challenges. ${ }^{8}$ It also allowed for an efficient distribution of risk, with individual underwriters taking only a percentage of any given insurance line. Lloyd's improved coordination of contracts between individual underwriters, allowing them to respond rapidly to potential business opportunities and diversify risk effectively. ${ }^{9}$ Conversely, the corporations had poorer access to information and faced a "lemons problem."10

Second, it was claimed that the marine corporations tended to act with extreme "caution," restricting the freedom of their underwriters, which led to higher-priced premiums. ${ }^{11}$ This was despite holding significantly more capital, which potentially allowed the insurance of whole lines and offers of lower rates. The failure to exploit this advantage must be ascribed to weaknesses within the corporations' shared organizational and business model. ${ }^{12}$ However, no clear explanation for the motivation behind these restrictions has been advanced.

There are two significant limitations to these explanations. First, they are anachronistic. It is important to note that Lloyd's was not, in 1720, the organized and efficient network it would later become. By the early eighteenth century, there was in excess of a 100 private underwriters in London, who had amassed extensive experience of routes and pricing, and informal networks provided platforms to enable coordination. Yet Lloyd's as a named entity was unknown in these years, and its "intelligence apparatus" only reached full development in the early nineteenth century. ${ }^{13}$

7. Kingston, "Marine Insurance in Britain and America, 1720-1844"; Westall, "Invisible, Visible and 'Direct' Hands."

8. Kingston ("Marine Insurance in Britain and America, 1720-1844"), Wright and Fayle (A History of Lloyd's), Straus (Lloyd's: A Historical Sketch), and Clayton (British Insurance) also underline the superior competitiveness of Lloyd's due to its better access and use of information.

9. John, "The London Assurance Company and the Marine Insurance Market," 133.

10. Akerlof, "The Market for 'Lemons."”

11. Supple, The Royal Exchange Assurance, 53; Leonard, "Contingent Commitment," 52-53.

12. Pearson and Doe, "Organizational Choice in UK Marine Insurance."

13. Raynes, A History of British Insurance; Gibb, Lloyd's of London; Kingston, "Marine Insurance in Britain and America, 1720-1844," 403; Clayton, British Insurance, 52 . 
Second, claims about the organizational superiority of the private underwriter networks are undermined by the development of the marine insurance industry in the United States. In the eighteenth century, American underwriters had followed Lloyd's model. ${ }^{14}$ However, their limited capital base forced merchants to spread their risk between underwriters. Newly formed joint-stock firms aggressively exploited this weakness, deliberately leveraging their capital advantage to insure entire ships. By 1810, the corporations had driven private underwriters almost entirely out of the market. ${ }^{15}$

At the time of their foundation, the LA and REA faced strong but not insurmountable competition. The U.S. case shows that the jointstock companies did not have an a priori worse organizational form or business model. Indeed, the success of the U.S. corporations was not the consequence of better information, it was rather the result of the strategic decision to aggressively exploit their capital advantage. This indicates that different organizational forms could succeed in the marine insurance sector and suggests the LA and REA had a similar opportunity in 1720 .

The limitations of these explanations open questions about the effects of organizational form on firm performance. Kingston called for "further study of the internal organisation of the British corporations ... to understand their comparative advantage and disadvantages relative to private underwriting." 16 This article pursues this line of inquiry and asks three questions: Why did entrepreneurs choose to use a novel organizational form in the marine insurance market? How were the new corporations organized and operated? What explains the "failure" of the eighteenth-century joint-stock companies to dominate the marine insurance industry?

In answering these questions the article considers John's observation that the structure of the LA, despite being a joint-stock firm, had an "absence of any delegated authority to a managerial hierarchy."17 Common to the period, the firm was directly managed by ownerdirectors. Yet various parliamentary debates in the late seventeenth and early eighteenth centuries expressed concerns about the allocation of rights and responsibilities among shareholders, directors, and managers. Problems of governance related to the constraint of managerial preference, the rotation of directors, and conflicts of interest caused

14. Crothers, "Commercial Risk and Capital Formation in Early America," 612.

15. Crothers, "Commercial Risk and Capital Formation in Early America"; Kingston, "Marine Insurance in Britain and America, 1720-1844."

16. Kingston, "Marine Insurance in Britain and America, 1720-1844," 406.

17. John, "The London Assurance Company and the Marine Insurance Market,” 131. 
by interlocking directorates were widespread. ${ }^{18}$ As Freeman and colleagues note, this was a period, "when the struggle over the powers of directors, who were usually owners, and nondirecting shareholders was particularly acute."19

This article examines how the organization and operations of the LA were adapted in response to three significant governance challenges. First, the struggle between directors and nondirecting shareholders could lead to controlling shareholders using the firm's assets for private benefit at the expense of small shareholders; a threat described as minority oppression. ${ }^{20}$ This problem was particularly acute in the case of owner-director-managed companies. There was limited legal protection of investor rights in eighteenth-century England, so to limit oppression, minority shareholders would have to seek protection through internal governance mechanisms.

The second challenge relates to the effectiveness of owner-directors in managing the firm. The lack of delegated management has been identified as a restriction on effective decision making. ${ }^{21}$ Recent research into "busy" non-executive directors posits that multiple appointments weaken oversight of management and lead to poorer firm performance. ${ }^{22}$ Supple identified the wide-ranging commercial and political interests held by directors of the REA, with interlocking directorates, a common feature of the chartered companies. ${ }^{23}$ The varied commitments of the LA's owner-directors, subsequent limitations on time, and possible conflicts of interest may have limited their capacity to monitor and control operations.

Third, limited liability is widely regarded as the "sine qua non of the modern company," critical in enabling diffuse corporate ownership. ${ }^{24}$ In eighteenth-century England, limited liability was not legally guaranteed, but could be included in the incorporating act. ${ }^{25}$ A lack of limited liability may have motivated large shareholders to exert close

18. Freeman, Pearson, and Taylor, Shareholder Democracies?, 77; Wagner, The English Chartered Trading Companies, 1688-1763, chap. 3.

19. Freeman, Pearson, and Taylor, Shareholder Democracies? p.11.

20. Lamoreaux and Rosenthal, "Corporate Governance and the Plight of Minority Shareholders”; Tirole, "Corporate Governance.”

21. Chandler, Strategy and Structure.

22. Fich and Shivdasani, "Are Busy Boards Effective Monitors?” A counter point is presented by Ferris and colleagues, who find no evidence that "busy" directors affect firm performance; Ferris, Jagannathan, and Pritchard, "Too Busy to Mind the Business?"

23. Supple, The Royal Exchange Assurance, 75-79; Wagner, The English Chartered Trading Companies, 1688-1763, 114.

24. Acheson and Turner, "The Impact of Limited Liability on Ownership and Control," 320; Kraakman et al., The Anatomy of Corporate Law.

25. Harris, Industrializing English Law; Freeman, Pearson; and Taylor, Shareholder Democracies?, 181-182. 
control of the company and, through the role of owner-managers, protect their investments from the risk of company failure and subsequent unlimited calls on their assets.

Analysis of the response of the shareholders and directors to these challenges is contextualized within eighteenth-century attitudes toward corporate governance. Shareholders were expected to be active participants in the operations of the company; as Pearson notes, "the passive investor was frowned upon." 26 Wider political interests, as well as local and national economic concerns, significantly influenced the behavior of shareholders. ${ }^{27}$ The analysis draws on a new data set of insurance lines made in the first year of operation, new data on the directors' external connections and personal business with the firm, and a number of new qualitative sources detailing the operations of the company.

The contribution of the article is twofold. First, it develops a different rationale for the relative failure of the LA, identifying that the directors adopted a risk-averse strategy due to organizational and strategic responses to governance challenges. The second contribution is to the debates on the evolution of the corporation. In the sixteenth century, innovations in the legal and organizational characteristics of the chartered trading companies created entities redolent of modern corporations, yet this was an incomplete revolution. ${ }^{28}$ Legal rights and responsibilities of owners and directors remained ill defined, and this article illustrates how these governance problems limited operations and performance. ${ }^{29}$ This supports explanations that dismiss the importance of the Bubble Act in explaining low levels of incorporation in the eighteenth century. ${ }^{30}$

The paper proceeds with a brief description of the British economy and marine insurance sector in the early eighteenth century. Examination of the parliamentary inquiry surrounding the proposed incorporation of the REA and LA identifies contemporary perceptions of the different organizational forms and the rationale for the change in ownership. Subsequently, the article details the organization and business model of the newly incorporated company. It concludes by contextualizing these findings within debates on organizational forms.

26. Pearson, "Shareholder Democracies?," 852.

27. Murphy, The Origins of English Financial Markets; Alborn, Conceiving Companies.

28. Gelderblom, De Jong, and Jonker, "The Formative Years of the Modern Corporation”; Turner, “The Development of English Company Law Before 1900.”

29. DuBois, The English Business Company After the Bubble Act, 93; Freeman, Pearson, and Taylor, Shareholder Democracies?, 180-182; Harris, Industrializing English Law, 129-130.

30. Turner, "The Development of English Company Law before 1900"; Harris, "The Bubble Act." 


\section{Britain's Evolving Economy in the Early Eighteenth Century}

The incorporation of the LA and REA in 1720 marked the completion of a lengthy, contentious debate between merchants, underwriters, and the British government regarding the benefits and threats of incorporation in the marine insurance sector. The debate, and the context in which it occurred, illustrate contemporary views of the joint-stock form and marine insurance.

The years 1719 and 1720 saw an extraordinary boom in the interest in the joint-stock form. More than 44 percent of all the British jointstock companies floated in the two centuries between 1600 and 1789 were floated in those two years. ${ }^{31}$ In addition to the sheer number of firms (at least 160 were floated), what is striking is the number of sectors involved: beside the traditional sectors of finance and long-distance trade, ventures in marine insurance, agriculture, consumer goods, and construction were proposed. ${ }^{32}$ Although dismissed by some contemporaries and historians as a fleeting effect of stockjobbers seeking to defraud the unwary public, these undertakings were part of a wider experimentation with the idea of publicly owned enterprises. ${ }^{33}$

Innovation of the corporate form was part of an evolution in the "sophistication and specialization of business activity" in the late seventeenth century. ${ }^{34}$ New ventures were often promoted on the basis of expanding business while providing some degree of public utility or benefit to the nation. The scale of capital within the ventures incorporated in 1720 was unprecedented, with some subscriptions rising above $£ 2$ million. Entrepreneurs, investors, and capital markets, were increasingly connected through these joint-stock ventures. ${ }^{35}$

Of all the sectors overtaken by the joint-stock euphoria, marine insurance raised by far the greatest interest among investors in Britain

31. Condorelli, "The 1719-20 Stock Euphoria," 23. The list of the English IPOs is mainly based on Scott, Constitution, op. cit.; and DuBois, The English Business Company After the Bubble Act, op. cit. The percentage must be taken as an approximation, as this computation has almost certainly missed a number of seventeenth- or eighteenth-century IPOs. Yet these would not be sufficiently numerous to significantly alter the relative importance of the years 1719-1720.

32. Anderson, An Historical and Chronological Deduction, [1762] 1801, III, p. 103 et seq., provides the most complete list of 1720 English joint-stock companies.

33. John Aislabie, chancellor of the exchequer in 1720, claimed the two marine insurance firms were: "founded in greater iniquity and contributed more to the publick calamity than anything else." Quoted in Scott, Constitution, 3:404. Bogatyreva, "England 1660-1720: Corporate or Private?," 198, expanded these claims: "The projectors were not aiming to revolutionise marine insurance for the benefit of trade and the nation; they were simply after profit."

34. Supple, The Royal Exchange Assurance, 3.

35. See Supple, The Royal Exchange Assurance, 5; Carlos, Fletcher, and Neal, "Share Portfolios in the Early Years of Financial Capitalism"; Murphy, The Origins of English Financial Markets. 
and northwest Europe. In Britain, the two marine insurance corporations became the two stars of the 1720 stock market bubble, their share prices surging to greater heights than the SSC.

Although not entirely novel-with previous joint-stock ventures mooted in Holland and Venice-the incorporation of the two British firms initiated a craze for marine insurance joint-stock companies elsewhere in Europe. In the Dutch Republic, thirty-nine out of forty joint-stock schemes projected between June and October 1720 were concerned with insurance. According to a London newspaper, the Dutch were so infatuated with insurance companies that they "talk[ed] of nothing else." 36 During that same time, two marine insurance firms were floated in Hamburg, their shares rising more than 100 percent in a week. ${ }^{37}$ Other marine insurance projects appeared in the Austrian Netherlands (July 1720), the Danish city of Altona (July 1720), and the northern German city of Emden (October 1720). ${ }^{38}$

The marine insurance craze took place against a backdrop of long-term expansion in international trade, with British imports and exports increasing by around 75 percent in the second half of the seventeenth century. ${ }^{39}$ There was growing interest from the state and among merchants to expand international trade; however, the significant risks involved stunted wider participation. The loss of individual ships could easily ruin a merchant, while events such as the destruction of the Smyrna fleet in 1693 threatened the wider economy. ${ }^{40}$ Marine insurance was recognized as a vital element in mitigating the threats faced by merchants.

In the seventeenth century, marine insurance operated through a system of brokers who linked merchants with underwriters. By 1720, there was in the region of 150 underwriters in London, the majority of whom were individuals who provided the service among a portfolio of business interests, often being merchants themselves. The individual underwriter would insure only a portion of a ship or its goods, with multiple underwriters insuring a single voyage. ${ }^{41}$

In the years before 1720, the networks of merchants, brokers, and underwriters were strengthened as locations such Edward Lloyd's

36. Applebee's Original Weekly Journal, July 23, 1720.

37. Amsinck, "Die ersten hamburgischen Assecuranz-Compagnien und der Aktien-handel im Jahre 1720." See also National Archives, SP 82/37, c. 108-123; Gazette d'Amsterdam, July 23, 1720; Post Boy, July 12 and 16, 1720.

38. Condorelli, "The 1719-20 Stock Euphoria."

39. Supple, The Royal Exchange Assurance, 5.

40. An Anglo-Dutch trading fleet was attacked by the French with more than ninety ships sunk and forty captured. In Britain it was estimated to be the biggest financial loss since the Great Fire of London.

41. For an account on how underwriters operated, see Hatton, Comes Commercii, 308; John, "The London Assurance Company and the Marine Insurance Market," 127-129; Sutherland, A London Merchant, 43-61. 
Coffee-house became hubs for conducting business. These hubs were, however, in their infancy in the early eighteenth century. There is also evidence that the marine insurance industry was plagued by many bankruptcies, with a reported 150 underwriters failing between 1718 and 1720 alone. $^{42}$

The growth in international trade raised the profile and attractiveness of the marine insurance industry. It is unsurprising that many merchants and entrepreneurs considered possibilities for innovation through the introduction of a joint-stock corporation. An intersection of interests, including those seeking to innovate financial services, and support private and public economic expansion, alongside speculative impulses of investors looking for further investment possibilities, saw a number of such schemes emerge in the early eighteenth century.

\section{The Incorporation Debate}

In 1717, a subscription was opened with the intent of raising $£ 1$ million to act as a fund for insuring ships and goods. ${ }^{43}$ This venture, which would become the REA, had an initial subscription of 286 individuals. Similar subscriptions were opened the following year for the LA. Both groups applied to the state for a charter of incorporation. A parliamentary select committee was formed to investigate and debate the arguments around incorporation in marine insurance. ${ }^{44}$

The inquiry occurred in a period of intense political scrutiny surrounding the chartered corporations. ${ }^{45}$ A series of parliamentary debates investigated the role and scope of the Hudson's Bay and Royal Africa Companies. Competing interest groups exploited these debates in attempts to reshape the institutional framework governing the economy. ${ }^{46} \mathrm{~A}$ constant source of contention was the extent to which the corporations were seen to support the national interest, in both economic and geopolitical terms. Counterclaims about the relative benefits of incorporation and monopoly became dominant themes.

Between 1717 and 1719, a number of petitions in favor of incorporation in the marine insurance sector were submitted to

42. Scott, Constitution, 3:400n4.

43. Scott, Constitution, 3:396.

44. The select committee had a wide remit to look at other subscriptions in life and fire insurance and to investigate the use of old charters for new purposes.

45. Wagner, The English Chartered Trading Companies, 1688-1763, 170.

46. Pettigrew, "Regulatory Inertia and National Economic Growth." 
Sir Edward Northey, the attorney general. ${ }^{47}$ In the case of the LA, initial subscriptions were raised by Stephen Ram and James Colebrook. These were heavily subscribed to by significant figures in the London mercantile community such as Jacob Eyles and John Lambert, alongside numerous stockjobbers. ${ }^{48}$ To navigate the petition through the parliamentary process, it was critical to obtain the support of major political figures, in the case of the LA these included Lord Chetwynd and Sir William Chapman, while the REA was organized around Lord Onslow.

The petitions expressed the public and private benefits that incorporation would deliver to shareholders, the insurance industry, trade, and the British economy. ${ }^{49}$ A corporation would offer a significantly securer organizational base, providing an attractive mechanism for investors to channel funds into the industry. ${ }^{50}$ Increasing the scale of capital would expand the capacity of the sector, ultimately increasing Britain's level of international trade.

The benefits of the corporate form were further broken down. First, it was expected to provide cheaper rates of insurance, in part by removing intermediation (i.e., brokers) from the process. ${ }^{51}$ Second, transactions would be easier and quicker, as a merchant could deal directly with a single entity, rather than requiring multiple policies from different underwriters. The promoters expected to insure whole ships, providing a new and easier service to merchants. ${ }^{52}$ Similarly, claims against policies would be settled more quickly, and the corporation's separate legal personality would allow merchants to sue the firm in case of dispute, rather than multiple individuals or partners. ${ }^{53}$ Finally, the petition argued that those working for the corporation "will be more diligent than single persons, the credit of the corporation depending on it." 54

All of these benefits were underpinned by the large capital base, over $£ 1$ million, which would ensure all policies could be settled,

47. Raynes, A History of British Insurance, 97-102.

48. Drew, The London Assurance, 4.

49. Bogatyreva, "England 1660-1720: Corporate or Private?" frames the debate as an effort by the proposers to secure personally profitable opportunities while presenting the outcomes in terms of the national interest.

50. LMA/CLC/B/192/MS08760, "Special report from the committee," p. 30. Case Billingsley (from the Royal Exchange Assurance syndicate).

51. LMA/CLC/B/192/MS08760, Summary of the petitions by Edward Northey, p. 26.

52. LMA/CLC/B/192/MS08760, Summary of the petitions by Edward Northey, p. 25. "The insurance will be quicker, there being only one subscriber, which will be done at once. Whereas by the method now used ... the office-keepers are to pick up the insurers here and there as they can."

53. LMA/CLC/B/192/MS08760, Summary of the petitions by Edward Northey, p. 26

54. Ibid. 
removing the threat of an individual underwriter being bankrupted and unable to meet the obligations.

In response, merchants and private underwriters submitted petitions against incorporation. On a fundamental level, they presented the corporation as an instrument of stockjobbers solely interested in profiting from increased share prices, with little care for the effects on the industry or British trade. ${ }^{55}$ Three specific arguments were proposed against the corporate model. First, it was claimed that the existing system managed by expert brokers generated rates lower than anywhere in Europe and attracted business from the Continent to London. ${ }^{56}$ Second, the establishment of a corporation would discourage private underwriters, resulting in knowledgeable individuals exiting the sector, leading to a rise in rates and a loss of this trade to markets such as Amsterdam. ${ }^{57}$ Third, it was noted that "a corporation has no sense of shame, as private persons have ... The dispatch of a corporation will not be like that of private persons." 58 In effect, according to the petitioners, the corporation would, by its very nature, be less efficient than private underwriters.

The threat of monopoly was widely debated. Both factions expected the corporations would capture the whole market, with the private underwriters fearing this would be achieved through monopoly. ${ }^{59}$ However, the pro-incorporation group insisted a monopoly was not their aim, and merchants would be free to choose between the corporation and private underwriters. ${ }^{60}$ Yet correspondence between the two, supposedly rival, corporations, indicates that they acted in concert, presumably expecting to form a duopoly once they had received their respective charters. ${ }^{61}$ Indeed, private underwriters worried that the two firms would lower prices to such an extent that they would drive competition out of the market, before raising rates once again. ${ }^{62}$

The debate highlighted the trade-offs between the effects of organizational forms on business and economic performance. The scale of capital, separate legal personality, and delegated management were

55. LMA/CLC/B/192/MS08760, "Special report from the committee," p. 30.

56. LMA/CLC/B/192/MS08760, Summary of the petitions by Edward Northey, p. 27.

57. Ibid

58. Ibid.

59. LMA/CLC/B/192/MS08760, p. 21. “[The market for marine insurance] may be so managed [by the new company] as entirely to fall into the corporation, to the great disappointment of the bold traders."

60. LMA/CLC/B/192/MS08760, Summary of the petitions by Edward Northey, p. 26.

61. Strauss, Lloyd's: A Historical Sketch, 31, 36.

62. LMA/CLC/B/192/MS08760, Summary of the petitions by Edward Northey, p. 27. 
identified as corporate features that could enhance the efficiency of operations, leading to lower rates and expanding the sector both domestically and internationally. Conversely, the petition presented the existing networks of brokers and private underwriters as highly knowledgeable and capable of efficiently pricing and diversifying risk. Disruption would make the sector uncompetitive. Finally, both petitions explicitly addressed principal-agent problems; one claiming the corporation would incentivize diligence, the other noting the lack of incentive to act with the "dispatch of a private person." 63 A notable omission from the debate, however, was any mention of limited liability, an issue not addressed by either side.

The initial response by the attorney general toward the charters was unfavorable, stating that the potential upheaval in the market caused by incorporation outweighed the proposed benefits. ${ }^{64}$ Yet the final settlement, encapsulated in the Bubble Act of 1720, was symptomatic of the range of interests involved in these debates. The two corporations received their charters, which prohibited entry of other joint-stock or partnership firms in the sector, but with the crucial provision that private underwriters would remain. However, one of the government's key interests was revealed, as both firms paid it a fee of $£ 300,000$ and made it a loan for the privilege of incorporation. ${ }^{65}$ Still, by June 1720 the proposers were formally in a position to start business.

\section{Establishing a Marine Insurance Corporation}

The debates established that the directors sought to leverage the scale of capital to achieve lower rates and dominate the sector. Once in possession of the charter, the directors needed to establish a model of corporate governance, a management structure, and a strategy to achieve these ends.

The charter itself detailed the key institutions of corporate governance: a general court of shareholders that elected and supervised a court of directors. ${ }^{66}$ The LA had a diffuse shareholder body, with an estimated 570 individual shareholders in $1720 .{ }^{67}$ A proportionate voting system was used to elect the court of directors from among this

63. LMA/CLC/B/192/MS08760, Summary of the petitions by Edward Northey, p. 27

64. Raynes, A History of British Insurance, 102-103.

65. Act of Parliament 6 Geo I, 18 (1720). Commonly known as the Bubble Act.

66. Act of Parliament 6 Geo I, 18 (1720).

67. LMA/CLC/B/192/MS08725C, "Account of shares," an account of early shareholders and shares. 
body, with the court of directors undertaking the day-to-day management of the firm. ${ }^{68}$ Directors were required to hold at least forty shares and had significantly larger holdings than the average subscriber. ${ }^{69}$ They were elected for a three-year term. ${ }^{70}$ The corporate governance structure and practices of the LA clearly copied other large jointstock companies such as the East India Company (EIC) and Bank of England (BoE). ${ }^{71}$

Meetings of the general court ostensibly offered the shareholders mechanisms to control the directors, yet effective control over the company lay with the elected directors. The separation of ownership and control was incomplete, with the directors, rather than professional managers, directly managing operations. To ensure that the directors were able to oversee the operations, the court, which was initially supposed to gather only once per month, rapidly decided to meet weekly. During the South Sea Bubble crash, between October 5 and 8, 1720, it even met daily. ${ }^{72}$ No director, however, held any fixed responsibility, with all serving on subcommittees with weekly turnover. The subcommittees were required to provide detailed reports for the court on a daily basis. The underwriting committee kept precise books of all the assurances taken and had to explain why it refused any contracts. ${ }^{73}$

The statutes contained clauses that sought to align the interests of the directors with the wider shareholder body. Including an "oath of fidelity to the corporation ... for the faithful discharge of their offices." 74 Moreover, they were prohibited from underwriting policies on their own account, taking presents for the "affairs" of the corporation, and buying shares of the REA. ${ }^{75}$

The directors represented various commercial and political interest groups. As Table 1 shows, twenty-four of the twenty-seven directors

68. Votes ranged from $£ 500$ ( 1 vote), $£ 1000$ ( 2 votes), $£ 3000$ ( 3 votes), and were capped at $£ 5000$ (4 votes).

69. LMA/CLC/B/192/MS08725C, “Account of shares,” an account of early shareholders and shares. Directors' shareholdings were a mean average of 2138 , in comparison to the average holding of 869.

70. LMA/CLC/B/192/8727A, Abstract book of rules, decisions, orders etc. relating to the administration and structure of the Corporation, p. 48.

71. Supple, The Royal Exchange Assurance, noted that the LA followed a "standard model as exemplified in others of the large-scale and well-established companies of seventeenth- and eighteenth-century England" (44); Cholmondeley Papers, Political papers, 88, n. 29, Department of Manuscripts, University of Cambridge, contains the LA's list of directors in 1720.

72. LMA/CLC/B/192/8727A, Abstract book, pp. 36, 38; LMA/CLC/B/08729/1, Opinions of Council, p. 39.

73. LMA/CLC/B/192/8727A, Abstract book, p. 9.

74. LMA/CLC/B/192/8727A, Abstract book, pp. 48, 165.

75. LMA/CLC/B/192/8727A, Abstract book, pp. 35, 48. 
Table 1 London Assurance directors' external connections and level of business undertaken through the firm

\begin{tabular}{|c|c|c|c|c|c|c|}
\hline Name & $\begin{array}{c}\text { Other } \\
\text { directorates }^{\mathrm{a}}\end{array}$ & $\begin{array}{c}\text { Other } \\
\text { commercial } \\
\text { interests }\end{array}$ & $\begin{array}{l}\text { Political } \\
\text { links }\end{array}$ & $\begin{array}{c}\text { No. of } \\
\text { external } \\
\text { connections }\end{array}$ & $\begin{array}{l}\text { No. of } \\
\text { lines } \\
\text { insured }\end{array}$ & $\begin{array}{c}\text { Total } \\
\text { coverage } \\
(£)\end{array}$ \\
\hline Chapman & SSC, ECC & Spain & Walpole ${ }^{b}$ & 3 & 2 & 8000 \\
\hline Chester & & & & 0 & 0 & 0 \\
\hline Chetwynd & & & MP & 1 & 0 & 0 \\
\hline Eyles & BoE, EIC & Turkey & $\begin{array}{c}\text { MP, } \\
\text { Walpole }\end{array}$ & 4 & 5 & 25,000 \\
\hline Flower & & & Walpole & 0 & 12 & 2365 \\
\hline Gaultier & SSC & Huguenot & & 2 & 4 & 995 \\
\hline Hatley & & North America & Walpole & 1 & 3 & 6900 \\
\hline Hopkins & SSC & Turkey & & 2 & 13 & 11,110 \\
\hline Hyde & & North America & Walpole & 1 & 9 & 13,750 \\
\hline Jacobsen & SSC, ECC & Hanse & & 2 & 0 & 0 \\
\hline Jamineau & & Huguenot & & 1 & 11 & 15,350 \\
\hline Jones & SSC & & & 1 & 5 & 1900 \\
\hline Lambert & SSC & Huguenot & & 2 & 9 & 1299 \\
\hline Lane & & Turkey & & 1 & 0 & 0 \\
\hline Martin & & Huguenot & Walpole & 1 & 5 & 2500 \\
\hline Neale & RAC & & Walpole & 1 & 14 & 14,300 \\
\hline Nelthorpe & & North America & & 1 & 14 & 7650 \\
\hline Osborn & SSC & & & 1 & 1 & 500 \\
\hline Radcliffe & & Turkey & & 1 & 1 & 300 \\
\hline Raymond & SSC & Turkey & & 2 & 2 & 2000 \\
\hline Richards & & Spain & & 1 & 23 & 21,870 \\
\hline Snelling & $\mathrm{LC}$ & Turkey & & 2 & 0 & 0 \\
\hline Stratton & & Turkey & & 1 & 1 & 1000 \\
\hline Vernon & & Turkey & $\begin{array}{c}\text { MP, } \\
\text { Walpole }\end{array}$ & 2 & 7 & 11,500 \\
\hline Watchter & RAC & & & 1 & 5 & 1850 \\
\hline Whitworth & & & & 0 & 0 & 0 \\
\hline Wordsworth & EIC, ECC & & & 2 & 10 & 2650 \\
\hline
\end{tabular}

a BoE, Bank of England; ECC, English Copper Company; EIC, East India Company; LC, Levant Company; RAC, Royal Assurance Company; SSC, South Sea Company.

b Robert Walpole was prime minister at this time.

Sources: LMA/CLC/B/192/MS30488, Marine Register 1720-21; Stow, A Survey of the Cities of London and Westminster, Borough of Southwark, 1733; McGilvary, East India Patronage and the British State, 2008; Bradburn and Coombs, eds. Early Modern Virginia: Reconsidering the Old Dominion, 2011; www.historyofparliamentonline.org; www.merchantnetworks.com.au. Also passim in this text. The list of other directorates and commercial and political interests is not exhaustive, but indicative of the nature of wider interests held by the directors.

had attested connections to other companies, mercantile groups, and political interests: eight directors were connected to the SSC, with others holding directorships in the BoE, EIC, and Royal African Company. Eight were "Turkey merchants," with interests in the Levant Company and extensive trading interests in the Mediterranean and Levant. A further four were Huguenots, with privileged ties to France and other French-speaking territories, such as Ostend. Three were part of the Virginia-Maryland mercantile lobby, and at 
least two were closely connected to the Spanish mercantile community. Indirect connections were also rife; Thomas Vernon, for instance, was the son of an EIC director, the brother of an REA director, and brother-in-law to an SSC director.

Two directors were MPs, while William Chapman was a close correspondent of the prime minister, Robert Walpole. ${ }^{76}$ Interestingly, a list of LA directors found in Walpole's correspondence was annotated with ticks, and while the exact meaning of the ticks is unknown, it is plausible that they were indicative of supporters or individuals fit to run for election. ${ }^{77}$ Joseph Eyles, who had two ticks, was elected in 1722, and was close to Walpole's administration.

One of the key challenges facing the management of the company was to mediate between these various groups and provide a system of checks and balances to avoid any one group controlling the firm for its own interest. In particular, it was essential to ensure that members of the underwriting committee could not take advantage of their position to grant preferential rates to themselves or to their factions. Clauses in the statutes were designed to deal with possible conflicts or deadlocks among the directorate. Any director could summon the court through a note in the London Gazette, "and such directors so assembled shall be deemed to be a Court of Directors and may transact the business of the corporation." 78 This mechanism can be inferred as serving two objectives: First, it allowed the court, in case of need, to act swiftly by gathering before the scheduled weekly meeting. Second, it prevented a minority from paralyzing decision making by simply not attending meetings. Other clauses enabled the court to act as an internal tribunal to "debate" the conduct of a director. ${ }^{79}$

These governance mechanisms, however, offered limited protection against the directors repressing the interest of minority shareholders. The majority of directors, twenty-one of the twenty-seven shown in Table 1, personally insured lines through the LA. ${ }^{80}$ A number of directors, such as John Richards and Henry Neale, made extensive use of the services, while directors, including Richards, Lambert, and Eyles, accounted for the majority the LA's business with Spain, Ostend, and the Levant.

There is evidence that some directors proposed clients to the underwriting committee, both in their own names and on behalf of

76. Carswell, The South Sea Bubble, appendix A.

77. Cholmondeley papers, Political papers, 88, n. 29.

78. LMA/CLC/B/192/8727A, Abstract book, p. 48.

79. LMA/CLC/B/192/8727A, Abstract book.

80. LMA/CLC/B/192/MS30488, Marine Register 1720-21. It is distinctly possible a greater proportion of the business was directly driven by the directors' with lines being purchased by merchants linked to their business interests. 
their wider interests. For instance, Thomas Vernon sat on the underwriting committee on July 9, 1721, when it underwrote four risks for himself, two for his fellow director John Richards, and two for another client, Richard Chiswell. Chiswell was an MP, a director of the BoE, and also a Turkey merchant like Vernon. ${ }^{81}$ Vernon and Richards were both directors, but they were also neighbors living in Coleman Street in London, where a third director, Martin, also lived. ${ }^{82}$ That Vernon personally oversaw the covering of risks for himself, for a neighbor and fellow director, and for a fellow Turkey merchant clearly constituted a potential conflict of interest.

One obvious solution to limit the scope for such conflicts was, at least in theory, to ensure that the underwriting committee was composed of members drawn from different groups or factions. However, in practice, the committee was plagued by regular absenteeism. In the case of Vernon, three out of the five members of the committee were absent that day. Beside himself, there was only one other director, Richard Stratton, present on the committee. Yet, Stratton was also a fellow Turkey merchant and insured his own ships with the LA. His presence on the committee exacerbated the potential conflict of interest, rather than mitigating it.

In an attempt to fight absenteeism, the corporation paid 5 shillings to each member of the court or the committees for each session they attended. ${ }^{83}$ The payment was likely remuneration for travel expenses, but can also plausibly be interpreted as a mechanism for fictionalizing the separation between owners and managers, with directors receiving the money to denote and remind them of their managerial role and responsibilities to the wider company. Either way, it is unlikely that the 5 shillings had a significant impact on the directors' behavior.

The issue of absenteeism became a significant problem for the company. Many of the directors simply could not dedicate sufficient time to attend to the company's affairs. Directors such as Sir William Chapman, John Lambert, and Joseph Eyles were prominent figures of the London business community. Nearly half of the directors sat on other boards, with three sitting as MPs, while the majority had other significant mercantile interests that made claims on their time. Directors that held at least two other attested significant roles (director, MP, or major commercial interest) alongside their position in the LA can be classified as busy. In this case, ten out of twenty-seven directors

81. LMA/CLC/B/192/MS30488, Marine Register 1720-21, July 7, 8, 9, and 11, 1720.

82. The Political State of Great Britain, 20: 459.

83. LMA/CLC/B/192/8727A, Abstract book, p. 9. 
were "busy" and unlikely to regularly attend the various weekly subcommittees that ran the day-to-day operations of the company. ${ }^{84}$

The underwriting committee, which met twice daily for a total of five hours, was particularly time-consuming, and absenteeism immediately became a major problem. In the first week of operation (July 4, 1720), John Lambert was almost always absent, and when not absent he arrived late. Out of five members, only two did not have at least one day of absence. ${ }^{85}$ There were instances when a director never attended. ${ }^{86}$

Absenteeism not only plagued the committees, but the court itself. To counter it, directors arriving more than one hour late, or leaving before the end of the meeting, would forfeit the five shillings. ${ }^{87}$ Moreover, to encourage full concentration on the company's business and avoid distractions, it was "ordered that no coffee or tea be carried into the room where the Courts of directors are sitting" and that a doorkeeper should prevent any outsider from "interrupting." 88 There is ample evidence that these procedures had limited success, and absenteeism remained a constant issue. In the most extreme case, a director could lose his position; a fate that befell Sir Francis Chester, who was absent "without leave" forty days in a row. ${ }^{89}$

Finally, while there had been no explicit mention of limited liability in the debate, a regime of pro rata limited liability was established in the articles. This made shareholders liable for company debt in proportion to their shareholding. ${ }^{90}$ In the 1720 s few constitutions included any clauses to limit liability. ${ }^{91}$ The decision to include any such stipulation indicate a sensibility toward the protection of shareholders. Such a regime, however, clearly burdened larger shareholdersthe individuals more likely to be directors.

\section{Creating a Strategy and Structure}

The directors of the LA had an existing model of corporate governance they could draw on, but they did not have a blueprint for the

84. Among other references, Street, The London Assurance, 1720-1920, 22.

85. LMA/CLC/B/192/MS30488, Marine Register 1720-21, July 4, 1720.

86. LMA/CLC/B/192/MS30488, Marine Register 1720-21, June 26, 1721, Joseph Eyles.

87. LMA/CLC/B/192/8727A, Abstract book, pp. 38, 48; LMA/CLC/B/08729/1, Opinions of Council, p. 52.

88. LMA/CLC/B/192/8727A, Abstract book.

89. LMA/CLC/B/08729/1, Opinions of Council, p. 20.

90. Freeman, Pearson, and Taylor, Shareholder Democracies?, 181.

91. Ibid, 184. In the authors' sample of 25 English firms incorporated between 1720 and 1789 , only three had limited liability clauses in their constitution. The authors note it was "probably not until the 1840s that limited liability could be identified as the chief distinguishing feature of the incorporated company." 
organization and management of a joint-stock firm in marine insurance. ${ }^{92}$ In the seventeenth century, the joint-stock form had primarily been used by long-distance trading companies operating under chartered monopolistic conditions. The marine insurance industry presented a different market structure and competitive dynamic for which there was no clear existing management model for a large joint-stock firm.

In its first two meetings, on June 24 and 28, 1720, the court attempted to structure the organization. The subcommittees responsible for the day-to-day business were defined: treasury, adjustments, accounts, and above all, the "committee for underwriting policies." 93 The firm recruited a number of "inferiour officers," but these had no power of decision, performing only administrative duties. One clerk was appointed "to keep the shipping ledgers" of the underwriting committee, while other clerks were responsible for the accounts. ${ }^{94}$ The court also ordered that "lists [presumably of ships], Lloyd's list, bills of entry, gazettes and other newspapers [should] be constantly taken in," 95 to ensure that all publicly available information on shipping and commercial markets was available to the directors. ${ }^{96}$

Many directors were experienced marine insurers, so the problem was not about understanding the business per se. ${ }^{97}$ The problem was how to conduct the business in a corporate rather than a private way. The directors needed to implement a management structure that would effectively link the court to the various committees-in particular the underwriting committee-achieving effective policy and decision making. The committees reported regularly to the court; in the case of the underwriting committee this included reports on lines covered, amounts, and rates. It was, however, initially unclear where ultimate authority and decision-making powers lay. ${ }^{98}$

The directorate does not seem to have explicitly stated a general strategy about customer acquisition and the best way to leverage the advantages of the corporation. The abstract book and minute book of

92. Scott, Constitution, 3: 383-384, 387. Although a number of fire and life insurance companies had been operating since the early 1700s, such as the Amicable Society and Sun Fire Office, they were significantly smaller firms and used a range of organizational forms, offering few clues to the large joint-stock LA.

93. LMA/CLC/B/192/8727A, Abstract book, pp. 9, 38.

94. LMA/CLC/B/192/MS8727A, Abstract book, p. 31.

95. Some newspapers, such as the Post Boy, gave daily news of ships arrivals and departures. See, for instance, Post Boy, July 9, 1720.

96. LMA/CLC/B/192/MS8727A, Abstract book, p. 139.

97. For instance John Richards, a prominent London agent of Bilbao merchants (see Lamikiz, Trade and Trust in the Eighteenth-Century Atlantic World, 38), or William Chapman, who passed to the London Assurance in July 1720 seventeen risks that he had underwritten himself: see the beginning of the 1720 Marine Register (LMA CLC/B/192/MS30488).

98. LMA/CLC/B/192/MS8727A, Abstract book, p. 9. 
the court contain a plethora of clauses relative to the corporate organization, absenteeism, and so on, but one looks in vain for a statement on strategy, assessing risks, the market, or the competition. A strategy only evolved at a later stage, as the result of internal debates among the directors. The underwriting committee simply opened for business on July $4,1720 .{ }^{99}$

The first line was proposed on July 6, 1720, and each proposed line was recorded in the marine register. ${ }^{100}$ The register included the date, name of the merchant, name of the ship, point of departure, point of arrival, any points at which the ship would stop, the amount insured, the premium rate, and the level of coverage. There were also comments for refusing a line or noting factors that affected the rate. These data can be used to identify patterns in the geographic coverage, premium rates, and levels of coverage to reveal the strategic preferences of the directors.

Between July 4 and December 31, 1720, 806 lines of insurance were proposed. Of these lines, 87 had incomplete information, missing either the destination, arrival, amount or rate. A further 47 lines were refused, and 53 lines were recorded as additional cover on existing policies. These have been removed but the additional amounts added to the original policy. ${ }^{101} \mathrm{~A}$ total of 187 lines were removed, leaving 619 lines for analysis.

Each line's departure and arrival point has been categorized into geographic regions: Great Britain (GB), western Europe, Africa, Caribbean, China, India, Ireland, Middle East and Levant, North America, northern Europe and Scandinavia, and South America. These data, shown in Table 2, found that departures and arrivals to and from British ports accounted for 72 percent of all the lines insured in this period. The routes to western European ports, with around 39 percent of all lines, were the dominant routes insured by the company. Northern Europe with 7 percent, North America at 6 percent, and the Caribbean with 6 percent were the other major areas of business.

The remaining 28 percent of lines were cross risks, or lines made where neither the departure nor the arrival port was the company's

99. Daily Post, July 12, 1720. Between July 2 and 4, 1720, the firm inserted daily press advertisements that announced the commencement of business.

100. LMA/CLC/B/192/MS30488, Marine Register 1720-21.

101. Of the remaining 619 lines, some appear to be additional coverage on existing policies. However, it is difficult to find a clean method to sort them. In many cases the names of the ships and journey details are the same, but the dates and the names of the merchants on the lines are different. There are two likely explanations for this. First, they were additional cover on the same journey, taken at a separate date. Second, they were different merchants insuring goods on the same ship. In either case, there is a potential overestimation in the number of separate journeys insured by the company. 
Table 2 Geographic location of the insured lines as a percentage of all lines insured

\begin{tabular}{lcc}
\hline Region & UK departures to & UK arrivals from \\
\hline Africa & $0.2 \%$ & $0.0 \%$ \\
Caribbean & $2.1 \%$ & $4.2 \%$ \\
China & $0.0 \%$ & $0.0 \%$ \\
India & $0.2 \%$ & $1.3 \%$ \\
Ireland & $0.8 \%$ & $0.6 \%$ \\
Middle East & $2.1 \%$ & $0.5 \%$ \\
North America & $2.6 \%$ & $3.7 \%$ \\
Northern Europe & $2.9 \%$ & $4.5 \%$ \\
South America & $0.0 \%$ & $0.0 \%$ \\
Great Britain & $7.1 \%$ & $0.0 \%$ \\
Western Europe & $25.8 \%$ & $13.4 \%$ \\
Total & $43.8 \%$ & $28.3 \%$ \\
\hline
\end{tabular}

Source: LMA CLC/B/192/MS30488, Marine Register 1720-21.

home city, London. A further distinction can be made between cross risks for which the other cities were in Britain and those entirely outside GB. Of the 233 cross risks, 60 were to or from British ports outside London, leaving a 173 non-British cross risks, or 28 percent of all the lines insured. Within the cross risks, a number of routes were significant; those arriving and departing within western Europe, routes between western Europe and South America, and those departing from Ireland.

Table 3 shows that across the 619 lines, a total of $£ 423,727$ was insured. The highest single line insured was for $£ 8000$ on an Ostend-Asia route. The lowest was $£ 25$ on a London to Hamburg voyage. The mean average was $£ 686$ per line. The average rate was 2.93 percent, ranging from 12.9 percent, again on the Ostend to China route, to 1 percent for various GB to western Europe routes. Cross-risks accounted for 34 percent of the total value insured.

Table 3 Descriptive statistics of the insurance amounts and rates

\begin{tabular}{lccccccc}
\hline All policies & $\begin{array}{c}\text { Total } \\
\text { insured }(£)\end{array}$ & $\begin{array}{c}\% \text { of } \\
\text { total }\end{array}$ & High $(£)$ & Low $(£)$ & Average $(£)$ & $\begin{array}{c}\text { No. of } \\
\text { lines }\end{array}$ & $\begin{array}{c}\% \text { of all } \\
\text { lines }\end{array}$ \\
\hline $\begin{array}{l}\text { Amount }(£) \\
\text { Rates }(\%)\end{array}$ & 423,727 & 100 & 8000 & 25 & 686 & 619 & 100 \\
$\begin{array}{l}\text { Excluding } \\
\quad \text { cross risks }\end{array}$ & & & 12.9 & 1 & 2.93 & & \\
$\begin{array}{l}\text { Amount }(£) \\
\text { Rates }(\%)\end{array}$ & 250,885 & 59.2 & 7000 & 25 & 645 & 386 & 62 \\
$\begin{array}{l}\text { Non-UK } \\
\quad \text { cross risks }\end{array}$ & & & 12 & 1 & 2.35 & & \\
$\begin{array}{l}\text { Amount }(£) \\
\text { Rates }(\%)\end{array}$ & 142,212 & 33.6 & 8000 & 45 & 822 & 173 & 28 \\
\hline
\end{tabular}

Source: LMA CLC/B/192/MS30488, Marine Register 1720-21. 
They yielded higher than average rates, with non-GB cross risks averaging 4.3 percent.

Within these non-GB cross risks a number of extremely lucrative routes can be identified. Departures from western Europe to China and India, dominated by ships leaving from Ostend, provided over 5 percent of the total amount insured, with average rates of 11.3 percent. These were predominantly insured as round trips, with the rate encompassing the return journey between Europe and Asia. Similarly, trips from western European ports to South America, mostly Cadiz and Oporto to Buenos Aires and Vera Cruz, accounted for 9 percent of the total coverage insured, with rates of 2.98 percent on the outward journeys from Europe and 5.96 percent on the inbound journeys. The LA charged higher-than-average rates on these routes and offered higher levels of coverage.

There is ample evidence that the LA was heavily reliant on its directors and their networks to start and develop its business. The directors' business amounted to 156 lines, or 25 percent of all lines insured, for a total value of $£ 152,789$, or 36 percent of the total coverage. They also accounted for 38 percent of the lucrative non-GB cross risks. For example, Joseph Eyles took out five lines on London to Aleppo and Smyrna routes, but the value of these lines was $£ 25,000$, nearly 6 percent of the total coverage. ${ }^{102}$

\section{An Evolving Strategy}

The directors and their networks represented a precious asset for the company, but they did not constitute a captive market: the firm still had to propose competitive rates. Pricing of the premiums was a major issue from the very beginning of operations. On July 7, 1720, the LA "refused" its first risk, a ship from East India to London at 5 percent; according to the ledger, the company would have taken the risk at 6 percent. On July 12, it refused several other ships on the same East India route. ${ }^{103}$

The firm was caught between two conflicting requirements: First, restricting the flexibility granted to the underwriting committee, so as to limit potential conflicts of interests. Second, being flexible enough to be able to compete and gain market share. At first, the board simply decided to set premium guidelines. On July 13, 1720, William Chapman

102. These estimates do not necessarily account for the business undertaken by individuals in the directors' various networks, potentially accounting for a much larger portion of the total business.

103. LMA/CLC/B/192/MS30488, Marine Register 1720-21, July 12, 1720. 
provided a "memorandum" indicating the "main rates." 104 In November, the court asked the underwriting committee "to prepare a list of voyages and what premium they think proper on each and make as just a distinction as they can between ships and seasons." 105 The problem was what to do with these guidelines: should they be rigid, providing tight control over risks, or flexible, focused on raising market share?

There is evidence that during the first months of operation there was some scope for a competition-oriented approach to rates. ${ }^{106}$ Around mid-1721, though, this flexible approach started to become a more rigid policy, with a clear priority given to risk control. The profitable Ostend market was the first target of the new policy. Ostend ships traveling to the East Indies represented lucrative, but risky contracts, as they were considered interlopers by Britain and Holland. ${ }^{107}$ In June 1721, the court of directors decided that the underwriting committee could no longer grant insurances on these ships without its ad hoc permission. ${ }^{108}$ The English market was the second target. In the same month, the court ruled that no insurance should be taken under 42 shillings percent on the lines between London and other English ports, "even upon the best ships."

Strict limits on the rates were imposed on all lines by the end of 1721, with multiple examples of policies turned down because the client was asking rates that were below the levels that the underwriting committee could accept. ${ }^{109}$ However, the company had not entirely given up its objective of being competitive, and there was still scope for some flexibility. Yet it is significant that control over these decisions had been taken away from the underwriting committee and given to the court. In December 1721, for instance, the director David Martin appealed to the court to insure $£ 1000$ on a ship sailing from Leghorn to London at 30 shillings percent; the court accepted, adding, however, that for larger sums on the same ship the premium rate should not be fewer than 40 shillings. ${ }^{110}$

Besides the premiums, the total amount insured per line presented a further policy dilemma. A risk-averse approach was also adopted

104. LMA/CLC/B/192/MS30488, Marine Register 1720-21, July 13, 1720

105. LMA/CLC/B/192/MS8727A, Abstract book, p. 9.

106. See, for instance, the significant variation in the rates offered on European journeys in July 1720: LMA CLC/B/192/MS30488.

107. See Huisman, M., La Belgique commerciale sous l'empereur Charles VI, 126-132. The Dutch East India Company, in particular, seized several Ostend ships in 1718-19. See also Kessler, Lee, and Menning, The European Canton Trade 1723.

108. LMA/CLC/B/192/MS8729/1, p. 152, June 28, 1721.

109. LMA/CLC/B/192/MS8729, Minute book, for example, September 1, 1722 (to Alicante), September 5, 1722 (Venice), September 7, 1722 (Denmark and Norway).

110. LMA/CLC/B/192/MS8729, Minute book, December 6, 1721. 
in this regard. In December 1720, the firm took a key decision, when William Chapman passed to the underwriting committee a lucrative contract for two Spanish ships sailing from Buenos Aires to Cadiz for a total of $£ 20,000$. The committee, declaring that it was "concerned" by the size of the contract, asked advice from the court. The sum was equivalent to 2 percent of the firm's nominal capital: a significant, but not an extravagant risk. Yet the Court did not follow Chapman's proposal, and decided instead to underwrite $£ 4,000$ on each of the ships. ${ }^{111}$

By the end of 1721, the strategy to exploit the scale of the capital by offering large single lines of insurance and low premiums becamse difficult to execute. In terms of scale, though, it is worth noting that the LA appears to have provided larger than average lines of insurance. John noted that the average line among private underwriters was $£ 50$ to $£ 100$ in 1700 , and double that in $1750 .{ }^{112}$ Even taking $£ 200$ as a benchmark, the LA’s average of $£ 686$ was significantly higher. In the first six months of operation, 115 lines were covered, with values between $£ 1000$ and $£ 5000$, with a further 5 lines valued up to $£ 8000$. Yet increasingly rigid rules curtailed the freedom of the underwriting committee to accept such large lines.

The sources indicate that in its first six months of operations, the LA was able to insure a wide geographical range of lines. While the majority of the business was in the intra-European and North America routes, where high levels of competition led to low rates, a significant proportion was in more lucrative cross-risk lines. Through the directors' networks the firm was able to pursue profitable opportunities, particularly on Asian and South American routes. Why, in spite of these opportunities, did the court of directors arrive at the decision to reduce the flexibility and competitiveness of the underwriting committee?

\section{Explaining These Outcomes}

Contrary to the argument about asymmetric information, the scope of the business indicates that the LA did not immediately suffer from a significant information deficit. In the first years, before Lloyd's became an information powerhouse, the LA may even have had an information advantage over private underwriters. The firm could benefit from the aggregation of the networks and knowledge of the

111. LMA/CLC/B/08729/1, Opinions of Council, p. 74.

112. John, "The London Assurance Company and the Marine Insurance Market,” 137. 
many well-connected merchants and businessmen who composed its directorate, and it also systematically collected all publicly available information on shipping and trade. It is debatable whether many private underwriters in 1720 would have had access to such a wealth of news and contacts.

If the firm did not immediately suffer from an information deficit, what then prevented it from capturing a larger share of the market? In light of the stated aims of the subscribers in the incorporation debate, why didn't the directors leverage the LA's key competitive advantage, the scale of its capital, to insure large sums and whole voyages? Why, contrary to what private underwriters had feared, didn't the LA also use its capital to finance a short-term aggressive pricing policy to systematically undercut the competition? Why did the directors adopt a risk-averse strategy?

It has been argued that the directors never intended to develop a viable marine insurance business, and rather sought to use the capital for other stock-jobbing purposes or to pay down the government fees stipulated in the charter. ${ }^{113}$ A conservative strategy would have, then, been a natural outcome. Yet two factors refute this argument. First, the size of the business and breadth of lines contracted in the first year indicates that the LA seriously attempted to establish a competitive venture. Second, it was a common strategy among insurance companies to manage their capital proactively through investments, ${ }^{114}$ a strategy also adopted by other firms in this period. ${ }^{115}$ In this respect, the portfolio of securities and loans does not appear overly speculative, and significant capital was deployed in the underwriting business.

The sources analyzed in this article show that the risk-averse strategy for premiums and level of coverage emerged over time, on a case-by-case basis, as a consequence of the balance of power within the court of directors. Despite the attempts to build a competitive position in 1720-1721 and despite the availability of capital and knowledge, the directors progressively arrived at the decision to not pursue the risky and demanding task of capturing a large share of the marine insurance market. It is important to note that the court did not unanimously agree with this decision. On the contrary, evidence suggests that there were debates between "hawkish" directors (including Chapman, Martin, and Neale), advocating a more aggressive approach

113. Bogatyreva, “England 1660-1720: Corporate or Private?,” 198.

114. Supple, The Royal Exchange Assurance, 73, found that both firms held BoE and SSC stocks, and EIC bonds and annuities. John, "Insurance Investment and the London Money Market of the 18th Century," 148-149, found that by 1726, the LA had a total of $£ 43,590$ in loans.

115. Wagner, The English Chartered Trading Companies, 111, identified the proactive management of securities by the Hudson's Bay Company. 
focused on higher risk and value policies, and "doves," advising a more prudent course of low risks and steady returns. Through these debates, a collective preference for the low-risk approach emerged in the court of directors, and likely in the general court as well.

This outcome can plausibly be explained as a function of the three corporate governance challenges identified in the article. First, a very competitive strategy, based on low premiums and insuring whole ships, may have increased market share, but there is no doubt that it would have greatly benefited those directors, and their factions, using the LA to insure their own ships. The threat of minority oppression would explain the risk-averse strategy as a mechanism to check the efforts of a small group of directors to use the company's assets for their own benefit.

This possibility was on the minds of many in 1720 and 1721, due to the crisis triggered by the South Sea Bubble. Contemporaries almost unanimously considered that a "junto" (inner ring) of reckless and unchecked directors had been the main culprit for the South Sea debacle. ${ }^{116}$ It is plausible that some of the LA's directors and shareholders were wary of seeing a similar junto, possibly formed by the hawkish directors, develop inside the firm. Indeed, the widespread use of governance mechanisms such as elections and term limits for directors indicate the wider concerns with threats of business capture and minority oppression. While these mechanisms offered theoretical scope to restrict these outcomes, reality was more problematic. Proportionate voting, stock qualifications, and control of the general court's procedures gave large shareholders and incumbent directors great scope in controlling access to the court of directors. ${ }^{117}$ In the case of the LA, stringent regulations around risk were important additional mechanisms to prevent opportunistic behavior among the directors.

Second, there were problems with the implementation of a competitive strategy. This would have required careful and constant monitoring of the market and the capacity to respond rapidly to changing conditions. Although mechanisms to provide oversight and control of the underwriting committee through the court were theoretically in place, the large-scale absenteeism of the busy directors undermined their effectiveness, disrupting the balance of interests and capacity to monitor operations. Without delegated management, or directors fully committed to the task of overseeing the company, a prudent strategy with fixed rates and rules on coverage became a logical development to reduce the impact of busy or absent directors.

116. See Dickson, The Financial Revolution in England, 118-119.

117. Bowen, The Business of Empire, 67-68, discusses the limited rotation of EIC directors in the early eighteenth century. Freeman, Pearson, and Taylor, Shareholder Democracies?, 89-91. 
Finally, the pro rata limited liability regime was a threat to the larger shareholders in the event of bankruptcy. An overly aggressive strategy increased the levels of the company's capital exposed to riskier lines, amplifying the potential for such a catastrophic outcome. As directors tended to be larger than average shareholders, it is logical that some were incentivized to introduce a risk-averse strategy and reduce their personal exposure. The strength of this argument is limited, however, as some directors clearly favored a more aggressive strategy.

The directors experimented with the management structure and processes, seeking to balance the need for the underwriting committee to be responsive while preventing it from being captured by a dominant shareholder group. Collective control over insurance risk emerged as the best solution to prevent opportunistic behavior. As the directorate did not meet daily, collective control could not be achieved via timely feedback from the committee and direct oversight. Instead, it was achieved via a system of inelastic rules on premiums and sums insured. The underwriting committee was kept on a short leash, preventing any single director or faction from acting independently and pursuing his own interests during his term.

Moreover, two further issues plagued the committee: first, a lack of specialization and continuity because of the weekly shifts in personnel; and second, chronic absenteeism. The most experienced and knowledgeable directors were, therefore, not systematically ensured to be present when meeting clients and assessing the risks. This restricted the efficiency of the LA's underwriting committee while limiting its capacity to leverage the knowledge of the directors. Conversely, overtime private underwriters increasingly benefited from network effects derived from the nascent Lloyd's setup.

Rigid rates and the tight supervision exercised by the court limited possible conflicts of interest, but severely reduced the LA's capacity to respond rapidly and meet the needs of potential customers. As a result, the underwriting committee, the linchpin of the whole business, lacked autonomy. This was a serious drawback in a very competitive market such as marine insurance.

\section{Conclusion}

Previous explanations of the relative failure of the British marine insurance corporations have claimed the business model of the private underwriters, in particular the capabilities developed by Lloyd's, as superior in reducing the effects of asymmetric information, making them more competitive. By contrast, this article demonstrates that 
after incorporation the LA did not suffer from an information deficit that precluded successful competition with the private underwriters. Instead of an a priori worse business model, the article identifies a period in mid-1721, toward the end of the first year of operations, when the directors intentionally adopted a risk-averse strategy.

While previous research has noted the great caution with which the LA approached the market, it has not provided a full explanation as to when and why this risk-averse approach was adopted. This article shows that the strategy was a by-product of efforts to develop governance mechanisms to reduce the scope for minority oppression, in the absence of full limited liability, and to limit the effects of significant levels of absenteeism among busy directors on the management of the firm. This resulted in a suboptimal management structure that constricted the underwriting committee through rigid rules and supervision, which severely limited its capacity to exploit the firm's capital advantage and drive the private underwriters out of the market.

Conversely, the nascent Lloyd's network was given the time and opportunity to establish the organizational capabilities that would later become so effective in addressing the "lemons" problem. It is likely these factors became increasingly important in explaining the ongoing failure of the corporations to grow their market share, as the scale and geographic reach of the marine insurance industry expanded over the century, exacerbating the problems of asymmetric information.

These findings have wider implications for the debates on the evolution of the corporation. The 1720 Bubble Act is generally regarded as a major restriction on the proliferation of the joint-stock form in the eighteenth century. ${ }^{118}$ While the act played a role, it certainly does not constitute the only explanation. In particular, the Bubble Act cannot explain the declining interest in the joint-stock form in the rest of Europe in the years after $1720 .{ }^{119}$

The case of the LA supports explanations that identify the post1720 decline in the number of the incorporated firms being, in part, a response to the inherent governance problems of the corporate form. This was a period when investors and entrepreneurs became increasingly cognizant of the governance and organizational challenges of implementing shareholder democracies, the decision-making problems associated with owner-directors, and issues of leveraging the corporations' advantages to compete in diverse industries.

118. In contrast, Turner claims that it is a "popular yet mistaken belief is that the Act hindered the development of the corporate form in England and set financial capitalism in England back by a century." Turner, "The Development of English Company Law Before 1900,” 127.

119. A question raised by Frehen, Goetzmann, and Rouwenhorst, "New Evidence on the First Financial Bubble," 605. 
Needless to say, further research is necessary to advance this hypothesis. However, evidence points to similar difficulties experienced by joint-stock firms floated across Europe in 1719-1720. ${ }^{120}$ The evolution of the Stad Rotterdam, a marine insurance firm launched in Rotterdam in 1720, is strikingly similar to that of the LA, with an increasingly conservative strategy imposed on the underwriters in $1722 .{ }^{121}$ The challenges of governance provide more robust hypotheses than the Bubble Act to explain the decline across Europe, and not simply in Britain.

This opens new questions and perspective. The "corporate revolution," begun by the institutional breakthroughs of the seventeenth century, was far from complete in the eighteenth century. Its completion required not only further legal developments, to strengthen limited liability and the protection of investors, but also managerial experimentation to identify governance and organizational structures to more effectively leverage the form's advantages in different industries.

Bibliography of Works Cited

\section{Books}

Alborn, T. Conceiving Companies: Joint-stock Politics in Victorian England. London: Routledge, 1998.

Bowen, H. The Business of Empire: The East India Company and Imperial Britain, 1756-1833. Cambridge: Cambridge University Press, 2006.

Bradburn, D., and J. Coombs, eds. Early Modern Virginia: Reconsidering the Old Dominion. Charlottesville: University of Virginia Press, 2011.

Carswell, J. The South Sea Bubble. Stroud, UK: Allan Sutton, 1993.

Chandler, A. Strategy and Structure: Chapters in the History of the American Industrial Enterprise. Cambridge, MA: MIT Press, 1974.

Clayton, G. British Insurance, London: Elek Books, 1971.

Dickson, P. The Financial Revolution in England: A Study in the Development of Public Credit 1688-1756. London: Macmillan, 1967.

Drew, B. The London Assurance: A Second Chronicle. Plaistow, UK: Curwen Press, 1949.

DuBois, A. B., The English Business Company After the Bubble Act, 1720-1800, New York: Octagon Books, 1971. First published 1938.

Freeman, M., R. Pearson, and J. Taylor. Shareholder Democracies? Corporate Governance in Britain and Ireland Before 1850. Chicago: University of Chicago, 2012.

120. Many incorporated firms in 1719-1720, such as the Vienna Company, the Milanese Casa di San Giuseppe, and the Lorraine Company, quickly failed. Other firms, such as the Venetian Trading Company and the Kassel Kommerzbank, achieved far lower returns than expected. Condorelli, "The 1719-20 Stock Euphoria." 121. Go, Marine Insurance in the Netherlands 1600-1870, 218-222. 
Gibb, D. Lloyd's of London: A Study in Individualism. London: MacMillan, 1957.

Go, S. Marine Insurance in the Netherlands 1600-1870: A Comparative Institutional Approach. Amsterdam: Amsterdam University Press, 2009.

Haines, F. Chapters of Insurance History; The Origin \& Development of Insurance in England. London: Post Magazine \& Insurance Monitor, 1926.

Harris, R. Industrializing English Law: Entrepreneurship and Business Organization. Cambridge: Cambridge University Press, 2000.

Huisman, M. La Belgique commerciale sous l'empereur Charles VI. La Compagnie d'Ostende. Brussels: Lamertin, 1902.

Kessler, M., K. Lee, and D. Menning. The European Canton Trade 1723: Competition and Cooperation. Berlin: de Gruyter, 2016.

Kraakman, R., P. Davies, H. Hansmann, G. Hertig, K. Hopt, H. Kanda, and E. Rock. The Anatomy of Corporate Law: A Comparative and Functional Approach. Oxford: Oxford University Press, 2004.

Lamikiz, X. Trade and Trust in the Eighteenth-Century Atlantic World: Spanish Merchants and Their Overseas Networks. Woodbridge, UK: Boydell Press, 2013.

McGilvary, G. East India Patronage and the British State. London: I. B. Tauris, 2008.

Murphy, A. L. The Origins of English Financial Markets Investment and Speculation Before the South Sea Bubble. Cambridge: Cambridge University Press, 2009.

Pearson, R., and T. Yoneyama, eds. Corporate Forms and Organizational Choice in International Insurance. Oxford: Oxford University Press, 2015.

Raynes, H. A History of British Insurance. London: Sir Isaac Pitman \& Sons, 1948.

Scott, W. R. The Constitution and Finance of English, Scottish, and Irish Jointstock Companies to 1720. 3 vols. Cambridge: Cambridge University Press, 1910-1912.

Straus, R. Lloyd's: A Historical Sketch. London: Hutchinson \& Co., 1937.

Street, G. The London Assurance, 1720-1920. London: Williams \& Norgate, 1920.

Supple, B. The Royal Exchange Assurance: A History of British Insurance, 1720-1970. Cambridge: Cambridge University Press, 1970.

Sutherland, L. A London Merchant, 1695-1774. Oxford: Oxford University Press, 1933.

Wagner, M., The English Chartered Trading Companies, 1688-1763: Guns, Money and Lawyers. Abingdon, UK: Routledge, 2018.

Wright, C., and C. C. Fayle, A History of Lloyd's. London: MacMillan, 1928.

Journal Articles, Chapters in Books, Papers, and Theses

Acheson, G., and J. Turner. "The Impact of Limited Liability on Ownership and Control: Irish Banking, 1877-1914.” Economic History Review, 59, no. 2 (2006): 320-346. 
Akerlof, G. "The Market for 'Lemons': Quality Uncertainty and the Market Mechanism." Quarterly Journal of Economics, 84, no. 3 (1970): 488-500.

Amsinck, C. "Die ersten hamburgischen Assecuranz-Compagnien und der Aktien-handel im Jahre 1720." Zeitschrift des Vereins für hamburgerische Geschichte, 9 (1894).

Bogatyreva, A. "England 1660-1720: Corporate or Private?" In Marine Insurance Origins and Institutions, 1300-1850, edited by A. B. Leonard, 178-203. London: Palgrave Macmillan, 2016.

Carlos, A. M., E. Fletcher, and L. Neal. "Share Portfolios in the Early Years of Financial Capitalism: London, 1690-1730.” Economic History Review, 68, no. 2 (2015): 574-599.

Condorelli, S. "The 1719-20 Stock Euphoria: A Pan-European Perspective." MPRA Paper, 2014. https://mpra.ub.uni-muenchen.de/82821.

Crothers, A. "Commercial Risk and Capital Formation in Early America: Virginia Merchants and the Rise of American Marine Insurance, 17501815." Business History Review, 78, no. 4 (2004): 607-634.

Ferris, S., M. Jagannathan, and A. Pritchard. "Too Busy to Mind the Business? Monitoring by Directors with Multiple Board Appointments." Journal of Finance, 58 (2003): 1087-1111.

Fich, E., and A. A. Shivdasani "Are Busy Boards Effective Monitors?" Journal of Finance, 61 (2006): 689-724.

Frehen, R., W. Goetzmann, and K. Rouwenhorst. "New Evidence on the First Financial Bubble.” Journal of Financial Economics, 108, no. 3 (2013): 585-607.

Gelderblom, O., A. De Jong, and J. Jonker. "The Formative Years of the Modern Corporation: The Dutch East India Company VOC, 1602-1623." Journal of Economic History, 73, no. 4 (2013): 1050-1076.

Guinanne, T., R. Harris, N. Lamoreaux, and J.-L. Rosenthal. "Putting the Corporation in Its Place." Enterprise and Society, 8, no. 3 (2007): $687-729$.

Harris, R. "The Bubble Act: Its Passage and Its Effects on Business Organization." Journal of Economic History, 54 (1994): 610-627.

John, A. "Insurance Investment and the London Money Market of the 18th Century." Economica, 20, no. 78 (1953): 137-158.

— . "The London Assurance Company and the Marine Insurance Market of the Eighteenth Century." Economica, 25, no. 98 (1958): 126-141.

Kingston, C. "Marine Insurance in Britain and America, 1720-1844: A Comparative Institutional Analysis." Journal of Economic History, 67, no. 2 (2007): 379-409.

Lamoreaux, N., and J.-L. Rosenthal. "Corporate Governance and the Plight of Minority Shareholders in the United States Before the Great Depression." In Corruption and Reform: Lessons from America's Economic History, edited by Edward Glaeser and C. Goldin, 125-152. Chicago: University of Chicago Press, 2006.

Leonard, A. "Contingent Commitment: The Development of English Marine Insurance in the Context of New Institutional Economics, 1577-1720." In Questioning Credible Commitment: Perspectives on the Rise of Financial 
Capitalism, edited by D’M. Coffman, A. Leonard, and L. Neal, 48-75. Cambridge: Cambridge University Press, 2013.

Musacchio, A., and J. Turner. "Does the Law and Finance Hypothesis Pass the Test of History?" Business History, 55, no. 4 (2013): 524-542.

Pearson, R. "Shareholder Democracies? English Stock Companies and the Politics of Corporate Governance During the Industrial Revolution." English Historical Review, 117, no. 473 (2002): 840-866.

Pearson, R., and H. Doe. "Organizational Choice in UK Marine Insurance." In Corporate Forms and Organizational Choice in International Insurance, edited by R. Pearson and T. Yoneyama, 47-67. Oxford: Oxford University Press, 2015.

Pettigrew, W. "Regulatory Inertia and National Economic Growth: An African Trade Case Study, 1660-1714." In Regulating the British Economy, 16601850, edited by P. Gauci, 25-40. Farnham, UK: Ashgate, 2011.

Tirole, J. “Corporate Governance.” Econometrica, 69 (2001): 1-35.

Turner, J. "The Development of English Company Law Before 1900." In Research Handbook on the History of Corporate and Company Law, edited by H. Well, 121-141. Cheltenham, UK: Edward Elgar, 2018.

Westall, O. "Invisible, Visible and 'Direct' Hands: An Institutional Interpretation of Organizational Structure and Change in British General Insurance." Business History, 39, no. 4 (1997): 44-67.

\section{Archival Sources}

Cholmondeley Papers. Political papers, 88, n. 29. Department of Manuscripts, University of Cambridge.

London Metropolitan Archive (LMA)/CLC/B/192/8727A, Abstract book of rules, decisions, orders etc. relating to the administration and structure of the Corporation.

LMA/CLC/B/192/MS08725C, "Account of shares," an account of early shareholders and shares.

LMA/CLC/B/192/MS30488, Marine Register 1720-21.

LMA/CLC/B/08729/1, "Minute book of the court of directors."

LMA/CLC/B/192/MS08760, "The special report from the [Parliamentary] committee appointed to inquire into, and examine the several subscriptions for fisheries, insurances, annuities for lives, and all other projects carryed on by Subscription, in and about the cities of London and Westminster; and to inquire into all undertakings for purchasing joint stocks, or obsolete charters."

National Archives, Secretaries of State: State Papers Foreign, Hamburg, SP 82/37, cc. $108-123$.

\section{Published Primary Sources}

Anderson, A. An Historical and Chronological Deduction of the Origin of Commerce. London: 1801. First published 1762.

Applebee's Original Weekly Journal, July 23, 1720.

Daily Post, July 12, 1720.

Gazette d'Amsterdam, July 23, 1720. 
Hatton, E. Comes Commercii. London, 1747.

A Letter to Jasper Vaux [...] in which the [...] extent of marine assurance are examined, by a subscriber to Lloyd's. London, 1810.

The Political State of Great Britain. Vol. 20, London, 1720.

Post Boy, July 9, 12, and 16, 1720.

Stow, J. A Survey of the Cities of London and Westminster, Borough of Southwark. London, 1733.

A true and exact particular and inventory [...] of Sir William Chapman. London, 1721. 